\title{
Influence of Market Day Activity on Entrepreneurship Values to Early Age Children
}

\author{
Leonita Siwiyanti", Indra Zultiar, Asep M. Ramdan \\ Universitas Muhammadiyah Sukabumi
}

*Corresponding Author: Leonita Siwiyanti, Universitas Muhammadiyah Sukabumi, Indonesia

\begin{abstract}
Market day activity is one of enterpreneur learning activity, where the main aim of this activity is to train and introduce the way of marketing while the target is their close friends, parents, teachers and others. Generally, this activity takes form as bazaar or the market that attempted by school in the end of their learning terms and ussually at AisyiyahBustanulAthfal 1 kindergarten, Sukabumi is attemped in the end of semester to show their main event of the activity them for the whole 6 months, Every class will show their frutation of hard work and will be offered to sell and served in nice packaging and promoted on their own beatutifully decorated stunts.
\end{abstract}

This research main purpose is to know the possitive integration between market day acctivity and enterpreneurship values at every early age children in AisyiyahBustanulAthfal 1 kindergarten, Sukabumi and to know how big the influence is.

Based on this research the researcher got $R$ result as 0,850 point, which means the correlation between variables of market day activity on the introduction of the values of enterpreneurship as 0,850 point. That matter shows us there is a strong influence between the activity of market day and the introduction of enterpreneurship value, because the point almost reaching 1 point. Meanwhile on R2 got 0,722 point which means the influenced percentage of market day activity on the introduction of enterprenurship values as 72,2 and the rest of 27,8\% that influenced by another variables that not included in the components. With 72,2\%as percentage the influence of application of enterprenurship values on early age children is surprisingly significant.

$F$ count value $=31,234$ with significants as 0,000 with using of significants limit as 0,0005, so significants $0,000<0,05$ HORejected and Ha accepted.

Thus, the hypothesis which explain that variables of market day activities have a great influence on the introduction of enterpreneurship values on early age children of AisyiyahBustanulAthfal 1 kindergarten, Sukabumi can be accepted.

Keywords: Market Day, Enterpreneurship Values, Early Age Children

\section{INTRODUCTION}

Many kind of opinion said that entrepreneur at Indonesia still lack in many aspect compared with other economical bustling countries, with the amount of citizen more than 200.000.000 approximately, surprisingly only $0,2 \%$ citizen who decide to become an entrepreneur. This matter happens because of lackness in the introduction of the values of entrepreneurship since the early stage in formal education. Because of that matter, the introduction of entrepreneurship is truly necessary since their early stage of childhood.

One of the kind of enterpreneurship that can be applied on educational world is the students should a great will, active and creative, innovative, leadership, and struggle for increasing their income upon their enterpreneurship activity. Meanwhile, some expalnations conclude that enterpreneurship is the very form of someone who have skill in making a good use of even of slightest chance in purpose of developing their entrepreneurship frutation in aim of making their life better (Kemendiknas,2010): 1520

A big portion of people thinks that enterpreneurship value cannot be learned but we call it as a very long process (learning by doing) and the main conscious for enterpreneurship is creativity. But there is also people who say opposite for this matter, they said enterpreneurship can be learned at formal 
education or institution, and the learning process of enterpreneurship is truly important in educational environment. Where in the environment of education, we are not only here to take a chance on job, but making it is necessarily important (Siwiyanti,2017)

The form of enterpreneurship introduction in educational environment, one of the form is the implementation of market day. Based on Phillip Kotler, marketing is kind of social activity and adjustment that attempted by an individual or a group in mean to achieve to get everything they wanted with a way of making product and exchange them with certain nominal value to the other party. So we can say that marketing activity is a whole process to fulfill the consumer needs which is implemented to maximize the profit of the company. Matters that covering the marketing activities is determining product, determining price, post- selling service (packaging and promotion) and selling (goods distribution). (Kotler, Philip and Keller, 2009)

So through market day the introduction of enterpreneurship for early age children in aim of tempering their will of struggle and their mind to become an entrepreneur. Not only to learn how to run a bussiness, but this learning process could also make the mental and personality of our children firmer and stronger than before. This matter is truly useful for understanding themselves, how to control their emotional state and stress, time management, communicative and easily to adapt in many kind of situations, also capapble to make and choosing right decision.

The value of enterpreneurship is better to be emerged as early as they can, and to maintain that value, teacher also have a role to continue giving the value gradually and it will be coming right into the children mainset and because of that they can make value for unused goods and making a great use to them and also the children will have struggle behaviour and not afraid upon anything that will come in the future. (Asmani,2011)

Market day activity is one of enterpreneur learning activity, where the main aim of this activity is to train and introduce the way of marketing while the target is their close friends, parents, teachers and others. Generally, this activity takes form as bazaar or the market that attempted by school in the end of their learning terms and ussually at Aisyiyah Bustanul Athfal 1 kindergarten, Sukabumi is attemped in the end of semester to show their main event of the activity them for the whole 6 months, Every class will show their frutation of hard work and will be offered to sell and served in nice packaging and promoted on their own beatutifully decorated stunts.

One of the main program was already implemented by many kindergarten, the activity takes form as market day, market day is a summit theme activity for elementary and kindergarten learning activity in a whole semester, showing their result of creativity or selling them to teacher,parents, and friends. Market day mainly used for giving the value of enterpreneurship, with the process of making, packaging and selling.

\section{DISCUSSION}

In the main event of market day the situation was made in cheerful and happy vibe, where some of the students is promote and selling ther original product, while the others is providing anyone who will buy their product and the smll group of student receiving the money. And most of them had extra money, they have money more than ussual. So they can buy more foods, beverages, souvenirs and toys that offered at market day. the income from the activity is mainly used for run the class activity, and also some of the money were stored in their own savings. With this very activity the resercher hope that the children who joined this activity will be educated about promoting and selling goods. And the children also will get used in honesty concept, such as scaling, meassuring, good or bad condition of their product.

The implementation of market day and the buying and selling activities are fundamentally same. So there are some theories that need to be concerned carefully based on Marketing Mix, that matters consisted from 4 main components :

- Product ,is anything that promoted to other people for them to see, hold, buy or consume. Products are consisted from :product variety, quality, design, feature, brand name, packaging, sizes, services, warranties, and returns.

- Price, is a specific amount of money that customer used for paying the products or changing some parts of the selling goods. 
- Place, is many kind of selling activities for producing the selling goods and will be available for the market or consument.

- Promotion, is various activities that conclude the process of communication and product introduction to the consument directly.

For market day implementation the children was prepared by learning 4 main components for this activity :

- Children have ability to make their own product, a sell able goods based on their own original work, ex : photo frame made from ice cream stick, decorated pencil, book divider.

- Children decided the price for their own product based on the dificulty production cost, but ussually in market day activity, the students are not giving their product a high price and the maximum price measurement is determined by parents, guardian, and teacher, so the price level is in the same rate.

- As for the stunts, guided by their teachers and parents the children decorating their own stunts.

- The last thing is the childrean learning to promote their own product to the consuments with implementing direct communication with telling them the name of the product and the specific price. The children also could learn economical math directly and can sustain them when they need to make a transaction call.

There is several way to indroduce the value of enterpreneurship for early age children especially kindergarten students(4-6years old), yaitu :(Jufri, $2014: 139-146)$

- Through cause and effect integration

the main purpose of this method is to make children adapt, involve and understand about cause and effect. The children count be directly involved in materials shopping process, and given understanding about the entrepreneur could make money because they make something to sell and of course we give the explanation about that matter as simple as we can.

- Learn from shape and picture

We ask the children to coloring a picture, drawing shapes, and draw lines from dot to dot and creating certain picture. Along with the activity of the children, the teacher and the parents could directly making an explanation to the children about the picture that they are working on. This kind of activity should be in cheerful and preferred and sort kind of pressure vibe Is not necessary to make them understand this activity purpose.

- Learning from story

Parents or teacher could give the children a valiant story of certain wonderous character. Usually they tells the story about a successful figure in enterpreneurship world and the main behaviors and habits that could lead them into the way of success. The story can be given other than a figure of enterpreneur, but we also can deliver a story about a great leader, great leader of honesty, wise and could be a great role figure to anyone else. There's a lot of story that can introduce enterpreneurship to our children.

- Learning about social capability

Social capability and teamwork with other people is growing as the development process goes by in responding their surrounding enviroment. The children also trained to work as a team. Their communication ability with others will also develop gradually. When they reach 4-7 years old we can give them more complex educative games, such as buying and selling simulation. There is several aspects that will be developed through this games, the aspects are : the development of social problem solving skill and negotiation and bargain skill. Along with the activity the confidence at self exploration using language and leader ability in their group.

\subsection{Research Variables and Operational Definitions}

\subsubsection{Research Variables}

According to Sugiyono(Sugiyono, 2017 : 2)Variable is everything that exactly decided by related researcher in aim for gathering the data and the researcher could conclude the result from their very own research object. Variable are divided in two that is independent variable and dependent variable. 
And the related variables are:

- Independent Variable :Market day implementation

- Dependent Variable :Enterpreneurship values

\subsubsection{Operational Variable Definition}

a) Market day activity

This activity is a learning process that used as the main method at this research to several group of experiment, this research takes form as an activity in purpose of introducing enterpreneurship with making products, pricing, decorating stunt and products promotion. So in this activity, the children have to do sort kind of social drama, some of them become a sellers while the others become buyers

The steps for the children to conclude Market day activity are :

- Product :

$>$ Children can produce their own goods for selling.

$>$ Children can pack their own goods as creative as possible.

- Pricing :

Children can consider and decide about their goods selling price.

- Place:

$>$ Children can decorate their own very stunt

$>$ Children can work together for decorating their goods

- Promotion:

Children can communicate effectively in promoting their goods.

$>$ Children can attract other people to buys their goods.

While for class control is not implemented, this activity only introducing fundamental state of enterpreneurship with the role of selling and promoting ready to sell goods.

b) Enterpreneurship Value

The result of Market day activity is to introduce enterpreneurship value since the early stage of the children's age. And the implementable values are :

- Confidence :

Children can finish their work/assignment without help from their parents/teacher.

- Creative :

Children can make something from their own original idea

$>$ Children can pour their sense of imagination and art in their own current work

$>$ Children can prove themselves to be different and make a good use from the difference and turn them into advantage in their work.

- Dare to take risk

$>$ Children dare to do something that harder from the usual difficulty.

$>$ Children can face a new challenge., something that they never do before.

- Orientation on action :

$>$ Children can decide based on their initiative and get to work.

$>$ Children can concentrate and diligent in executing their work/assignment.

- Leadership :

$>$ Children can receive critics and suggestions full-heartedly. 
Children can co-exist with anyone.

$>$ Children can working with others.

$>$ Children can give a right direction about third assignment or even playing to others.

- Hard work

$>$ Children always do their best on finishing their work/assignment.

$>$ Children can solve and taking care many kindod obstacle when they are up in something.

- Honesty

$>$ Children can anything in truth.

$>$ Children can taking any action in honesty..

- Discipline

Children can do anything in order and obedient to the existing rules and course.

- Innovative

Children have a skill to implement their very own creativity when they playing or doing something.

- Responsible

$>$ Children can finish their work properly.

$>$ Children can undergoing their obligation in a right way.

- Realistic

Children have an ability to judge and do something based on their limitation.

- Curiosity

Children frequently asking about something new.

Children have a critical attitude to know whether everything they see and hear.

\subsection{Result of Validity and Reability Test}

\subsubsection{Result of Validity Observation Sheet Test}

The data of observation result after validity level test can be seen in following table :

Table2.1. Observation Sheet Validity Test

\begin{tabular}{|c|c|}
\hline Indicator/Statement & Result \\
\hline 1 & 0,776 \\
\hline 2 & 0,800 \\
\hline 3 & 0,766 \\
\hline 4 & 0,876 \\
\hline 5 & 0,842 \\
\hline 6 & 0,713 \\
\hline 7 & 0,786 \\
\hline
\end{tabular}

Case Processing Summary

\begin{tabular}{|l|l|r|r|}
\hline \multicolumn{2}{|c|}{} & $\mathbf{N}$ & \multicolumn{2}{c|}{$\%$} \\
\hline Cases & Valid $^{2}$ & 14 & 100.0 \\
\cline { 2 - 4 } & Excluded $^{\mathrm{a}}$ & 0 & 0 \\
\cline { 2 - 4 } & Total $^{2}$ & 14 & 100.0 \\
\hline
\end{tabular}

Source: data processing

Based on the upper table the result of observation sheet validity test using SPSS version 24 and consulted with $\mathbf{r}_{\text {table }}=0,457$ can be concluded that every question/statement on observation sheet every single data is accredited as a valid data, based on the calculation one of the item was found as $\mathbf{r}_{\mathrm{xy}}>\mathbf{r}_{\text {tabel }}$ as $0,776>0,457$. 


\subsubsection{Result of Observation Sheet Reability Test}

Based on observation sheet reability test using SPSS application version 24 and using cronbach's alpha formula, the researcher get Reliability Statistics Cronbach's Alpha as for 0,917 point.

Tabel2.2. Result of Reability Statistics

\begin{tabular}{|l|l|}
\hline \multicolumn{2}{|c|}{ Reliability Statistics } \\
\hline Cronbach's Alpha & N of Items \\
\hline .917 & 7 \\
\hline
\end{tabular}

The calculation result was consulted with 0,6 point ; based on the criteria of an instrument, it can be said that it is reliable if it has reability coefficient point as $>0,6$ and from the consultation result it can be concluded that the reability index was $0,917>0,6$; so it can be said that observation sheet instrument is reliable and can be used as research instrument

\subsection{Simple Linier Regretion Test}

Analysis of simple linier regretion was implemented in this very research in aim for hypothesis proving about the existance of market day $(\mathrm{X})$ variable influence with the existance of enterpreneurship value. Stastics calculation on simple linier regretion analisys was implemented in this research and using SPSS version 24. The whole result of SPSS data processor is existing in the table down below:

Table2.3. Result of Simple Linier Regretion Result Linier Sederhana

\begin{tabular}{|c|c|c|c|c|c|c|}
\hline \multicolumn{7}{|c|}{ Coefficients $^{\mathrm{a}}$} \\
\hline \multirow{2}{*}{\multicolumn{2}{|c|}{ Model }} & \multicolumn{2}{|c|}{ Unstandardized Coefficients } & \multirow{2}{*}{$\begin{array}{l}\text { Standardized Coefficients } \\
\text { Beta }\end{array}$} & \multirow[t]{2}{*}{$\mathbf{t}$} & \multirow[t]{2}{*}{ Sig. } \\
\hline & & $\mathrm{B}$ & Std. Error & & & \\
\hline \multirow[t]{2}{*}{1} & (Constant) & -1.155 & 13.434 & & -.086 & .933 \\
\hline & MARKETDAY & 3.384 & .606 & .850 & 5.589 & .000 \\
\hline
\end{tabular}

Source: Processed Data

Based on the upper table, the researcher can conclude that independent variable or market day activity (x) is possitively influencing dependent variable or enterpreneurship values (y) as for 0,850 .

\subsection{Hypothesis Test}

\subsubsection{Determination coefficient test $(R 2))$}

$\mathrm{R}$ Showing a double correlation, the explanation is a correlation between two or more independent variables on dependent variable. $R$ value calculated between 0 to 1 . If the value nearing 1 , it can be concluded as well-integrated data. In the other hand if the data nearing 0 point it can be concluded as less-integrated data.

$\mathrm{R}^{2}$ showing determination coefficient behaviour, this number is the form of charity Influence percentage of independent variable on dependent variable.

Table2.4. Summary Model

\begin{tabular}{|l|c|c|c|r|}
\hline Model & R & R Square & Adjusted R Square & Std. Error of the Estimate \\
\hline 1 & $.850^{\mathrm{a}}$ & .722 & .699 & 9.50438 \\
\hline \multicolumn{2}{|l}{ a. Predictors: (Constant), MARKETDAY } \\
\hline
\end{tabular}

Source: Processed data

$\mathrm{R}$ number has gained 0,850 point it means that the correlation between activity variable on enterpreneurship values as for 0,850 point. It means there was a well-integrated relationship because the point is nearing 1 .

In the other hand, $\mathrm{R}^{2}$ have value as 0,722 point it means the percentage of influence on market day activity on enterpreneurship values as for $72,2 \%$, while $27,8 \%$ was influenced by other variables tah not included in this very research.

\subsection{Homogenity Test (F)}

Hypothesis test simultaneously was implemented with using $\mathrm{F}$ Test. F test attempted for gathering information about the significant integration between independent variable and dependent variable generally. The results are: 
Tabel2.5. $A N O V A^{a}$

\begin{tabular}{|c|l|l|l|l|l|l|}
\hline \multicolumn{2}{|c|}{ Model } & Sum of Squares & df & Mean Square & F & Sig. \\
\hline \multirow{2}{*}{1} & Regression & 2821.430 & 1 & 2821.430 & 31.234 & $.000^{\mathrm{b}}$ \\
\cline { 2 - 7 } & Residual & 1083.998 & 12 & 90.333 & & \\
\cline { 2 - 7 } & Total & 3905.429 & 13 & & & \\
\hline
\end{tabular}

a. Dependent Variable: ENTERPRENEURSHIPVALUES

b. Predictors: (Constant), MARKETDAY

Source: Processed Data

Based on the test result the general regretion model $\mathrm{F}$ count value $=31,234$ with significants as 0,000 with using of significants limit as 0,0005, so significants $0,000<0,05 \mathrm{H}_{0}$ Rejected and $\mathrm{H}_{\mathrm{a}}$ accepted. And $\mathrm{H}_{1}$ Rejected and $\mathrm{H}_{2}$ accepted.

Thus, the hypothesis explain that :

- The is sort kind of integration between market day activity and enterpreneurship values at early age children.

- Market day activity had a significant influence on enterpreneurship values at early age children.

\subsubsection{Partial Test $(t)$}

For showing how far the the influence of an independent variable individually in explaining dependent variable variation. This is the following test result from each partial variable.

Based on main problem and research purpose, thus, the delivered hypothesis are :

$\mathrm{H}_{0}$ : There is no integration between market day activity $(\mathrm{x})$ and enterpreneurship values (y).

$\mathrm{H}_{\mathrm{a}}$ : There is an integration between market day activity $(\mathrm{x})$ and enterpreneurship values (y).

$\mathrm{H}_{1}$ : Market day activity did not have any influence on enterpreneurship values (y)

$\mathrm{H}_{2}$ : Market day activity did have influence on enterpreneurship values (y)

Based on table 2.3 the result of regretion variable test at market day activity on enterpreneurship values at AsyiyahBustanulAtfhal 1 kindergarten, Sukabumi showing t calculation value as $=5,589$ with significance as for 0,000 with using significant limit as 0,005 , then significance $0,000<0,05$, and $\mathrm{H}_{\mathrm{a}}$ accepted and $\mathrm{H}_{0}$ rejected, $\mathrm{H}_{1}$ acceptedand $\mathrm{H}_{2}$ rejected. Then we can conclude market day activity have an influence on enterpreneurship values at AsyiyahBustanulAtfhal 1 kindergarten, Sukabumi.

\subsection{Analysis of Market Day Influence on Enterpreneurship Value}

Based on Phillip Kotler, marketing is kind of social activity and adjustment that attempted by an individual or a group in mean to achieve to get everything they wanted with a way of making product and exchange them with certain nominal value to the other party. So we can say that marketing activity is a whole process to fulfill the consument needs which is implemented to maximize the profit of the company. Matters that covering the marketing activities is determining product, determining price, post-selling service (packaging and promotion) and selling (goods distribution). (Kotler, Philip and Keller, 2009)

Based on the theory above, market day activity is an important process in introducing enterpreneurship values to early age children, in aim for the children can develop their behaviour as an enterpreneur. It also useful in educational world, exactly for AisyiyahBustanulAthfal 1 kindergarten, Sukabumi that giving a statement as market day is one of the key in implementing enterpreneurship values to early age children.

In this research market day activity can prove that this event can give a significant influence on enterpreneurship values introduction to early age children at AisyiyahBustanulAthfal 1 kindergarten, This matter proven by the statistics result of data gathering and data processing, as : 
Table2.6. $A N O V A^{a}$

\begin{tabular}{|l|l|r|r|r|r|c|}
\hline \multicolumn{2}{|l|}{ Model } & Sum of Squares & df & Mean Square & F & Sig. \\
\hline \multirow{3}{*}{1} & Regression & 2821.430 & 1 & 2821.430 & 31.234 & $.000^{\mathrm{b}}$ \\
\cline { 2 - 7 } & Residual & 1083.998 & 12 & 90.333 & & \\
\cline { 2 - 8 } & Total & 3905.429 & 13 & & & \\
\hline
\end{tabular}

a. Dependent Variable: ENTERPRENEURSHIPVALUES

b. Predictors: (Constant), MARKETDAY

Source: Processed Data

Based on the table above, we can conclude that significance value is reaching 0,000 point. With using significance limit 0,005 , then value $0,000>0,005$ point. This matter has proven that statement above compatible with the research result that is market day activity can affect and give influence significanly with significance value as 0,000 point.

\section{Closing}

This research main purpose is to know and understand about the positive integration between market day activity and entrepreneurship value on early age children at AsyiyahBustanulAtfhal 1 kindergarten, Sukabumi and to realize how big the is the influence. Based on the research and discussion, we can conclude as :

- Market day activity has a positive integration on entrepreneurship value introduction as for 0,859 . This result indicates that market day activity have a significant influence on ernterpreneurship value, the reason is result of the value itself is almost reaching 1 point. Entrepreneurship value consisted from 12 aspects, such as : confidence, creative, dare to take risk, orientation on action leadership, hard work, honesty, discipline, innovative, responsible, realistic and curiosity. With percentage market day activity influencing as $72,2 \%$ and the rest $27,8 \%$ influenced by any other variable, in the implementation, market day activity at AsyiyahBustanulAtfhal 1 kindergarten, Sukabumi shows that it can be positively influencing on entrepreneurship values introduction to early age children.

- Market day activity is truly influencing on entrepreneurship value to early age children, with significance value as $0,000<0,005$ this matter caused by market day activity that continuously implemented at AsyiyahBustanulAtfhal 1 kindergarten, Sukabumi. From the observation sheet distribution to students of AsyiyahBustanulAtfhal 1 kindergarten, Sukabumi, generally they are very enthusiast and active in the learning process and early implementation of entrepreneurship value.

\section{REFERENCES}

[1] Abidin, M. (2007). Seri Wirausaha Yang Tepat. Jakarta: Yayasan Bina Karya Mandiri.

[2] Asmani, J. . (2011). Sekolah Entrepeneur. Jakarta: Harmoni.

[3] Basrowi. (2016). Kewirausahaan untuk Perguruan Tinggi (2nd ed.). Bogor: Ghalia Indonesia.

[4] Jufri, M. dan H. W. (2014). Internalisasi JIwa Kewirausahaan Pada Anak (cetakan ke). Jakarta: Kencana.

[5] Kasmir. (2008). Kewirausahaan. Jakarta: PT. Raja Grafindo Persada.

[6] Kemendiknas. (2010). Pengembangan Pendidikan Kewirausahaan. Jakarta: Kemendiknas Badan Penelitian dan Pengembangan Pusat Kurikulum.

[7] Kotler, Philip and Keller, K. L. (2009). Manajemen Pemasaran (jilid 1) Edisi 13. Jakarta: Erlangga.

[8] Latipun. (2015). Psikologi Eksperimen. Malang: Universitas Muhammadiyah Malang Press.

[9] Ruseffendi. (2006). Pengantar Kepada Membantu Guru Mengembangkan Kompetensinya dalam Pengajaran Matematika. Bandung: Tarsito.

[10] Siregar, S. (2015). Metode Penelitian Kuantitatif: Dilengkapi dengan Perbandingan Perhitungan Manual \& SPSS. Jakarta: Prenadamedia Group.

[11] Siwiyanti, L. (2017). Menanamkan nilai kewirausahaan Melalui Kegiatan Market Day. Golden Age, 1 No.1(Pendidikan Anak Usia Fini), 83-89. Retrieved from https://ejournal.unisba.ac.id/index.php/golden _age/article/view/2861/1958

[12] Sugiyono. (2014). Metode Penelitian Bisnis. Bandung: Alfabeta.

[13] Sugiyono. (2015). Metode Penelitian Pendidikan: Pendekatan Kuantitatif, Kualitatif, Dan R\&D. Bandung: Alfabeta. 
[14] Sugiyono. (2017). Statistika untuk Penelitian. Bandung: Alfabeta.

[15] Sukardi. (2015). Metodologi Penelitian Pendidikan. Jakarta: PT Bumi Aksara.

\section{AUTHORS' BIOGRAPHY}

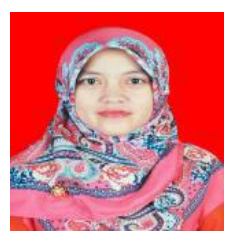

Leonita Siwiyanti, Lecturer of Faculty of Teacher Training and Education in Muhammadiyah University of Sukabumi. Interesting in Entrepreneurship

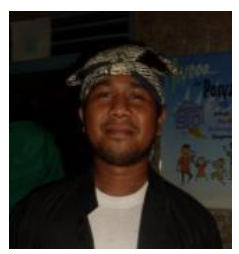

Indra Zultiar, Lecturer of Faculty of Teacher Training and Education in Muhammadiyah University of Sukabumi. Interesting in early childhood education programs

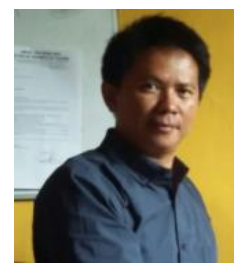

Asep Muhamad Ramdan, Lecturer of Faculty of Administrative and Humanities in Muhammadiyah University of Sukabumi. Interesting in Marketing Management.

Citation: Leonita Siwiyanti et.al. "Influence of Market Day Activity on Entrepreneurship Values to Early Age Children" International Journal of Managerial Studies and Research (IJMSR), vol 6, no. 8, 2018, pp. 42-50. doi:http://dx.doi.org/10.20431/2349-0349.0608005.

Copyright: (C) 2018 Authors. This is an open-access article distributed under the terms of the Creative Commons Attribution License, which permits unrestricted use, distribution, and reproduction in any medium, provided the original author and source are credited. 